\title{
Preparation of Zinc Tungstate (ZnWO $)$ Particles by Solvo-hydrothermal Technique and their Application as Support for Inulinase Immobilization
}

\author{
Eric da Cruz Severo ${ }^{a}$, Ederson Rossi Abaide ${ }^{a}$, Chayene Gonçalves Anchieta ${ }^{a}$, Vitória Segabinazzi Fo- \\ letto $^{b}$, Caroline Trevisan Weber ${ }^{a}$, Tais Bisognin Garlet ${ }^{a}$, Gabriela Carvalho Collazzo ${ }^{a}$, Marcio Antonio \\ Mazuttia, André Gündel , Raquel Cristine Kuhn ${ }^{a *}$, Edson Luiz Foletto ${ }^{a}$ \\ ${ }^{a}$ Department of Chemical Engineering, Federal University of Santa Maria - UFSM, 97105-900, Santa \\ Maria, RS, Brazil \\ ${ }^{b}$ Pharmacy Undergraduate Course, Federal University of Santa Maria - UFSM, 97105-900, Santa \\ Maria, RS, Brazil \\ 'Federal University of Pampa-UNIPAMPA, University Campus, 96413-170, Bagé, RS, Brazil
}

Received: February 05, 2015; Revised: July 14, 2015; Accepted: September 01, 2015

\begin{abstract}
$\mathrm{ZnWO}_{4}$ particles were synthesized as a single-phase by a simple and easy solvo-hydrothermal technique using water-ethylene glycol mixture as solvent, without using surfactant. Physical properties of produced particles were analyzed by X-ray diffraction (XRD), infrared spectroscopy (FTIR), surface area (BET), particles size distribution and atomic force microscopy (AFM). This material was used as support for inulinase immobilization by physical adsorption and the influence of temperature (30 and $50{ }^{\circ} \mathrm{C}$ ) was evaluated. Material with mesoporous characteristic and with a surface area of $35.5 \mathrm{~m}^{2} \cdot \mathrm{g}^{-1}$ was obtained. According to the findings, $\mathrm{ZnWO}_{4}$ present a satisfactory inulinase adsorption, and the

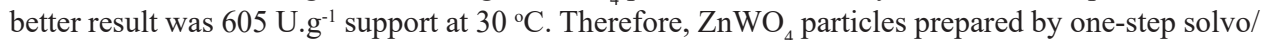
hydrothermal route provide a new potential support for inulinase immobilization.
\end{abstract}

Keywords: $\mathrm{ZnWO}_{4}$, synthesis, characterization, inulinase, immobilization

\section{Introduction}

Metal tungstates with formula $\mathrm{MWO}_{4}$ (where $\mathrm{M}$ is a divalent metal ion) are important ceramic materials that have high application potential in various technological fields ${ }^{1,2}$. Specifically zinc tungstate $\left(\mathrm{ZnWO}_{4}\right)$ have attracted attention due to its unique physical and chemical properties, possessing a high application potential in various fields, such as scintillator material $^{3}$, photoluminescence ${ }^{4}$, electronic and optical properties ${ }^{5}$, photovoltaic property ${ }^{6}$, humidity sensor ${ }^{7}$, hydrogen sensor ${ }^{8}$, ether sensor ${ }^{9}$, photocatalyst ${ }^{10}$ and high-power lithium-ion batteries $^{11}$. In this work, a new application is proposed for the $\mathrm{ZnWO}_{4}$ oxide, as support for enzymes immobilization.

The use of enzymes has been increased in the last years due the variety application such as food production, medicine, textile and pharmaceutical ${ }^{12}$. Immobilization presents some advantages such as lowering downstream purification requirements because the products are easily removed from the immobilized enzymes ${ }^{13}$ and lowering the costs because enzyme can be reuse. Enzymes are supported in solid matrix for the immobilization by a variety of methods such as physical and chemical mechanisms ${ }^{12}$. The physical adsorption of enzyme ${ }^{12,14}$ is entrapment on porous matrix, and in the chemical immobilization enzyme is attachment by covalent bonds ${ }^{15}$ and cross-linking between enzyme and matrix ${ }^{16}$. The immobilization by adsorption usually preserves the catalytic activity of the enzyme ${ }^{17}$, therefore, sometimes during its use the immobilized enzyme can be lost when the interactions between adsorbent and enzyme are relatively weak ${ }^{17,18}$, and in this case, the support can be reused. Inulinases are enzymes

*e-mail: raquelckuhn@yahoo.com.br useful on industrial processes, which can be applied for the production of sugars. It may produce high fructose syrups by enzymatic hydrolysis, and are used for the production of fructooligosaccharides, which are functional food ingredients. Inulinase has been immobilized by adsorption on different supports such as grafted alginate beads ${ }^{19}$, aminated non-porous silica $^{20}$ and chitin $^{21}$. However, the inulinase immobilization using the $\mathrm{ZnWO}_{4}$ oxide as support has not been explored yet.

$\mathrm{ZnWO}_{4}$ particles have been synthesized by various routes such as polymerized complex method ${ }^{22}$, microwave assisted technique ${ }^{23}$, hydrothermal ${ }^{24}$, ligand-assisted hydrothermal ${ }^{25}$, template-free hydrotherma ${ }^{26}$, solid-state reaction $^{27}$, polyol-mediated synthesis ${ }^{28}$, solid-state metathetic approach $^{29}$, mechanochemical synthesis ${ }^{30}$, sol-gel ${ }^{31}$, calcining co-precipitated precursor ${ }^{32}$ and combustion method ${ }^{33}$, electrodeposition ${ }^{34}$ and high direct voltage electrospinning process $^{35}$. In this work, $\mathrm{ZnWO}_{4}$ particles were prepared by the one-step solvo/hydrothermal method due be simple, easy, mild reaction temperature, and environmentally friendly, because use not surfactant.

In this context, we aimed prepare $\mathrm{ZnWO}_{4}$ particles by one-step solvo-hydrothermal route and investigate their ability as support for inulinase immobilization.

\section{Experimental Procedure}

\subsection{Preparation and characterization of $\mathrm{ZnWO}_{4}$}

$\mathrm{ZnWO}_{4}$ support was prepared by solvo/hydrothermal method using sodium tungstate $\left(\mathrm{Na}_{2} \mathrm{WO}_{4} \cdot 2 \mathrm{H}_{2} \mathrm{O}\right)$ and zinc chloride $\left(\mathrm{ZnCl}_{2}\right)$ as starting materials. For the material synthesis, 0.14 
$\mathrm{g}$ of sodium tungstate was dissolved in $20 \mathrm{~mL}$ of solution containing deionized water and ethylene glycol $(1: 1, \mathrm{v} / \mathrm{v})$, under magnetic stirring by $30 \mathrm{~min}$. The same procedure was taken to $\mathrm{ZnCl}_{2}$, however using $0.13 \mathrm{~g}$. The sodium tungstate solution was added into the zinc chloride solution under magnetic stirring. Then the resulting homogeneous solution was transferred into Teflon-lined stainless-steel autoclave. This autoclave was sealed and maintained at $180{ }^{\circ} \mathrm{C}$ for 24 $\mathrm{h}$ and then cooled to room temperature. The obtained white powers were collected and washed with deionized water and ethanol for several times to remove impurities, and then the product was dried at $110{ }^{\circ} \mathrm{C}$ for $4 \mathrm{~h}$.

$\mathrm{ZnWO}_{4}$ particles were characterized by X-ray diffraction (XRD), Fourier transform infrared spectroscopy (FTIR), BET surface area measurement, particles size distribution and atomic force microscopy (AFM). X-ray diffraction patterns were obtained using a Rigaku Miniflex 300 diffractometer. The X-ray source was $\mathrm{Cu}-\mathrm{K} \alpha$ radiation, powered at $30 \mathrm{kV}$ and $10 \mathrm{~mA}$. Data were collected over the $2 \theta$ range $10-70^{\circ}$ with a step size of $0.03^{\circ}$ and a count time of $0.9 \mathrm{~s}$ per step. By means of infrared spectroscopy, Fourier transform infrared spectra (FTIR) for all samples pressed into $\mathrm{KBr}$ pellets (10 $\mathrm{mg}$ zinc tungstate/300 $\mathrm{mg} \mathrm{KBr}$ ) were recorded by a Shimadzu IR-Prestige-21 spectrometer. IR spectra were measured in the range $3700-475 \mathrm{~cm}^{-1}$. Nitrogen adsorption-desorption isotherms were obtained from nitrogen adsorption isotherms at $77 \mathrm{~K}$, carried out on an ASAP 2020 apparatus at relative pressure $\left(\mathrm{P} / \mathrm{P}_{0}\right)$ ranging from 0 to 0.99 . The particle size distribution of sample was measured using a laser particle size analyzer (Mastersizer 2000). The morphology of particles was examined by atomic force microscopy (AFM) (Agilent Technologies 5500 equipment). Before analysis, the sample was sonicated in acetone for 15 min to break up the possible agglomerates, and then dropped onto a freshly cleaved mica substrate. AFM image was acquired at room temperature, in non-contact mode using high resolution probes SSS-NCL (Nanosensors, force constant $=48 \mathrm{~N} . \mathrm{m}^{-1}$, resonance frequency $=154 \mathrm{kHz}$ ). Image was captured and analyzed using PicoView 1.14.4 software (Molecular Imaging Corporation, USA).

\subsection{Enzyme immobilization assays}

Adsorption experiments were carried out to investigate the inulinase immobilization from aqueous solution. Commercial inulinase was obtained from Aspergillus niger (fructozyme, exo-inulinase EC 3.2.1.80 and endo-inulinase EC 3.2.1.7) was purchased from Sigma-Aldrich. The influence of temperature $\left(30\right.$ and $50^{\circ} \mathrm{C}$ ) on the immobilization process was investigated. The adsorption of inulinase was performed using a batch technique. Typically, $\mathrm{ZnWO}_{4}(0.025 \mathrm{~g})$ were placed in Erlenmeyers flasks containing of inulinase solution $(1.3 \% \mathrm{v} / \mathrm{v})$ in sodium acetate buffer $(\mathrm{pH} 4.8)$ and 1:400 of adsorbent:adsorbate ratio. The resulting solution was maintained under agitation (150 rpm), and then an aliquot of the aqueous solution was taken at various time intervals and filtered through a polyvinylidene difluoride (PVDF) membrane $(0.22 \mu \mathrm{m})$ before analysis. The inulinase activity in the aqueous solution was determined according to section 2.3.

\subsection{Inulinase Activity Assay}

An aliquot of the enzyme $(0.5 \mathrm{~mL})$ was incubated with sucrose solution $(4.5 \mathrm{~mL}, 2 \% \mathrm{w} / \mathrm{v})$ in sodium acetate buffer $(0.1 \mathrm{M}, \mathrm{pH}$ $4.8)$ at $50{ }^{\circ} \mathrm{C}$. Released reducing sugars were measured by the 3.5-dinitrosalicylic acid method ${ }^{36}$. A separate blank was set up for each sample to correct for the non-enzymatic release of sugars. One unit of inulinase activity was defined as the amount of enzyme necessary to hydrolyze $1 \mu \mathrm{mol}$ of sucrose per minute under the mentioned conditions (sucrose as a substrate). The inulinase immobilization capacity $\left(Q_{t}\right)$ was determined using the Equation (1).

$$
\mathrm{Q}_{\mathrm{t}}=\frac{\left(\mathrm{A}_{0}-\mathrm{A}_{\mathrm{t}}\right) \mathrm{V}}{\mathrm{m}}
$$

Where: $A_{o}$ and $A_{t}\left(\mathrm{U} \cdot \mathrm{mL}^{-1}\right)$ are the inulinase activities at $t=0$ and time $t$, respectively; $V(\mathrm{~mL})$ is the volume of solution, and $m(\mathrm{~g})$ is the mass of support.

\section{Results and discussion}

The XRD pattern of the $\mathrm{ZnWO}_{4}$ prepared through solvo/hydrothermal process is shown in Figure 1. The XRD peaks of $\mathrm{ZnWO}_{4}$ sample can be assigned to monoclinic $\mathrm{ZnWO}_{4}$, accordingly to JCPDS (Joint Committee on Powder Diffraction Standards) card No. 73-544, indicating that the synthesized sample is single-phase. The major diffraction peaks at $2 \theta$ of $18.89^{\circ}, 30.44^{\circ}, 36.43^{\circ}$ and $53.6^{\circ}$ correspond to the (100), (111), (002) and (221) planes of $\mathrm{ZnWO}_{4}$. The average crystallite size of $\mathrm{ZnWO}_{4}$ was calculated by the Scherrer equation ${ }^{37}$

$$
D=\frac{K \cdot \lambda}{h 1 / 2 \cdot \cos \theta}
$$

where $D$ is the average crystallite size, $K$ is the Scherrer constant $(0.90), \lambda$ is the wavelength of the $\mathrm{X}$-ray radiation $(0.1541 \mathrm{~nm}$ for $\mathrm{Cu}-\mathrm{K} \alpha), h_{1 / 2}$ is the peak width at half height and $\theta$ corresponds to the peak position (in the current study, $2 \theta=30.44^{\circ}$ ). The average crystallite size of $\mathrm{ZnWO}_{4}$ sample was $11 \mathrm{~nm}$.

The nitrogen adsorption-desorption isotherms and pore size distribution corresponding to $\mathrm{ZnWO}_{4}$ support are depicted in Figure 2. The nitrogen adsorption-desorption isotherms (Fig. 2a) showed weak adsorption at low relative pressure and a H1-type hysteresis loop at higher relative pressure $\left(\mathrm{P} / \mathrm{P}_{0}=0.70-0.90\right)$. This suggests that the material presents mesoporosity, which can be attributed to the interparticle pores due to the crystallites agglomeration. According to the IUPAC classification, the isotherms are type IV and typical of mesoporous solids. Pore size distribution (Figure 2b) consisted of one wide peak centered at around $15 \mathrm{~nm}$. The Brunauer Emmett-Teller (BET) surface area, average pore size and total pore volume of the $\mathrm{ZnWO}_{4}$ sample were $35.5 \mathrm{~m}^{2} \cdot \mathrm{g}^{-1}, 12.4 \mathrm{~nm}$ and $0.112 \mathrm{~cm}^{3} \cdot \mathrm{g}^{-1}$, respectively. These 


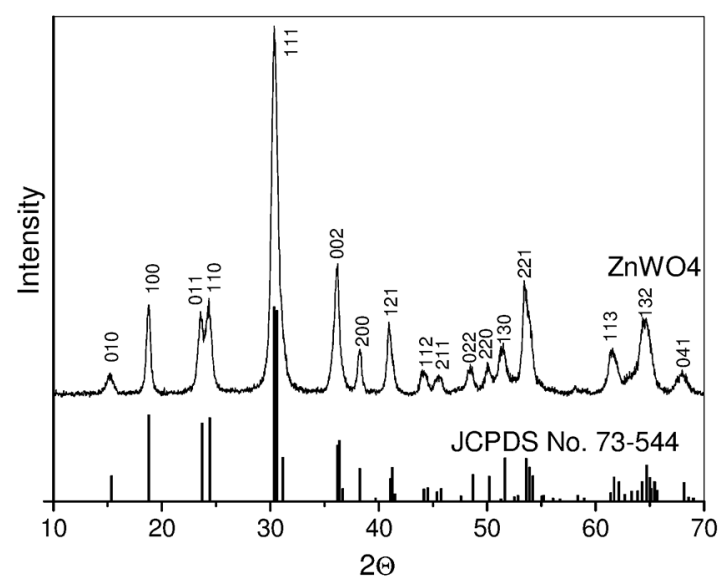

Figure 1: XRD pattern of $\mathrm{ZnWO}_{4}$ powders prepared by solvo/ hydrothermal crystallization. Inset at figure: $\mathrm{ZnWO}_{4}$ reference according to JCPDS card No. 73-544.
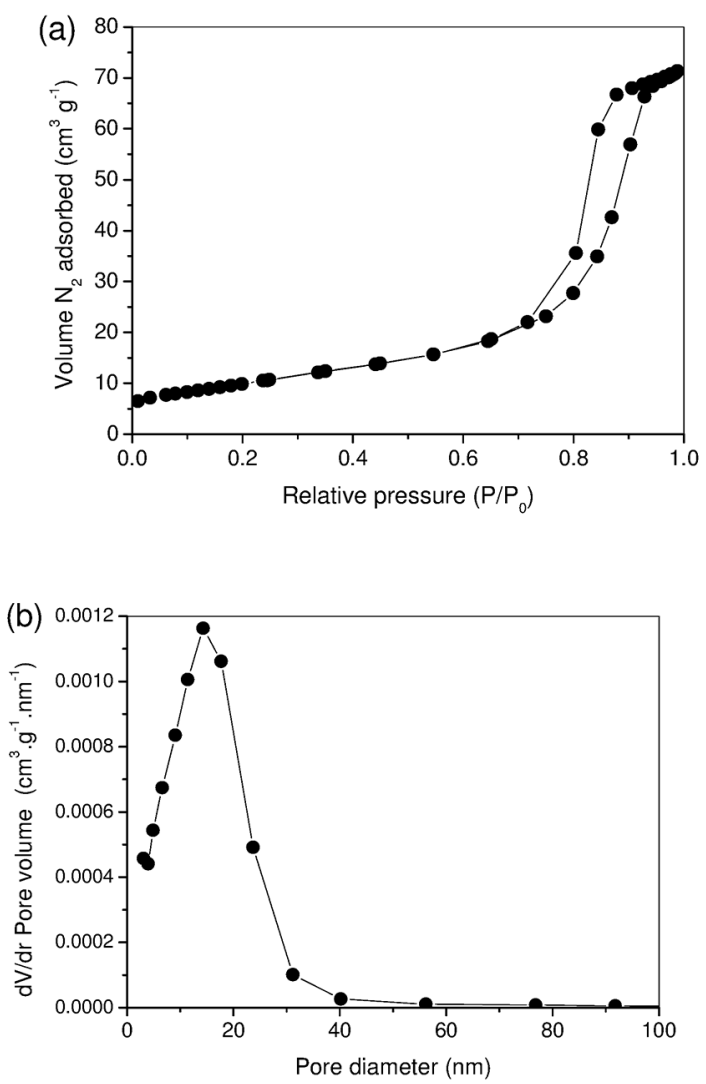

Figure 2: (a) Nitrogen adsorption-desorption isotherms and (b) pore size distribution curve of $\mathrm{ZnWO}_{4}$ support.

physical characteristics regarding the pores structure are essential for immobilization purposes by adsorption process.

The particle size distribution pattern for the zinc tungstate obtained by the solvo-hydrothermal technique was expressed on a logarithmic scale, as shown in Figure 3. The particles size for the oxide sample range between $0.30 \mu \mathrm{m}$ and 240 $\mu \mathrm{m}$, resulting in an average size of $26 \mu \mathrm{m}$. These particle

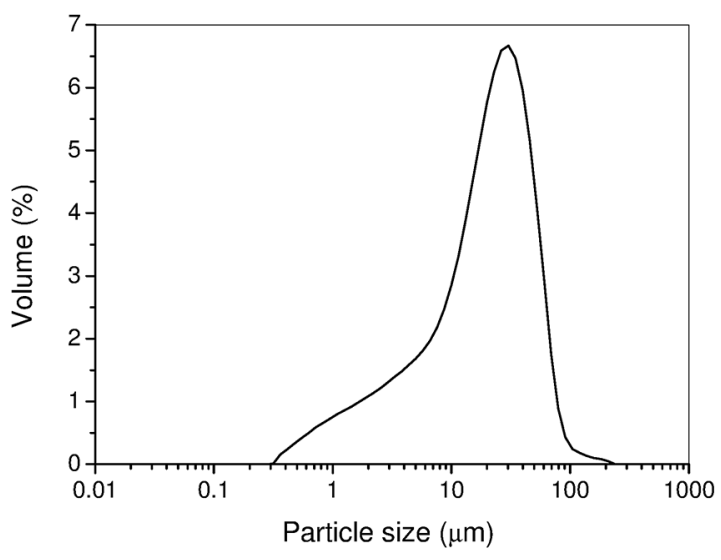

Figure 3: Particle size distribution plot for zinc tungstate prepared by the solvo-hydrothermal route.

sizes in micrometric scale can explain the mesoporosity of material due to a variety of accumulated pore voids among the particles formed by the agglomeration of crystallites. Thus this mesoporous structure can be interesting for enzyme immobilization purposes.

Figure 4 shows the morphology of some isolated particles of $\mathrm{ZnWO}_{4}$ oxide measured by atomic force microscopy (AFM). The average size of particles was around $0.30 \mu \mathrm{m}$. Also, it is possible to observe that the particles present an irregular shape.

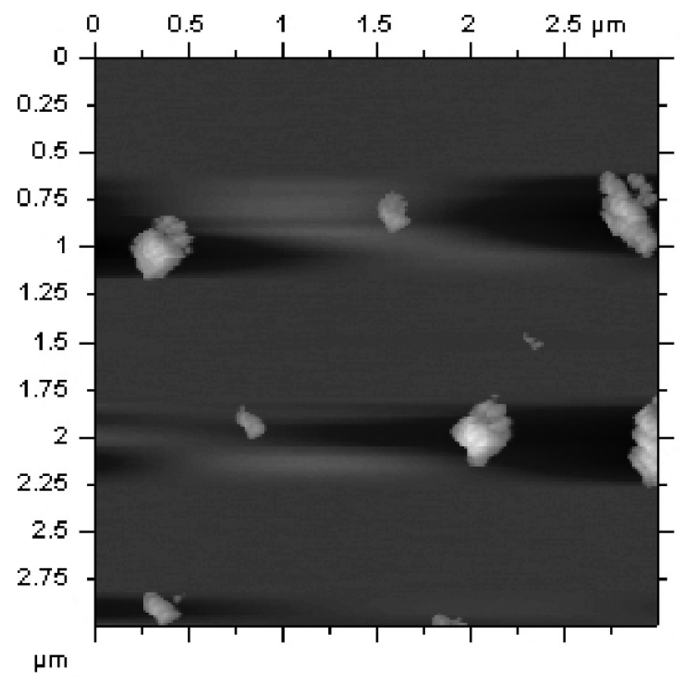

Figure 4: AFM image of some isolated particles of $\mathrm{ZnWO}_{4}$ sample after sonication.

In order investigate the immobilization of enzyme on the $\mathrm{ZnWO}_{4}$ support, FTIR spectra of $\mathrm{ZnWO}_{4}$ support, immobilized enzyme on the support and free enzyme were recorded (Figure 5). The $\mathrm{ZnWO}_{4}$ support (Figure 5a) shows main absorption bands between 475 and $1000 \mathrm{~cm}^{-1}$ 38. The bands to 820 and $880 \mathrm{~cm}^{-1}$ are due to the stretching modes of $\mathrm{W}-\mathrm{O}$ bonds. The bands at 600 and $700 \mathrm{~cm}^{-1}$ are assigned to $\mathrm{Zn}-\mathrm{O}-\mathrm{W}$ bonds. Bands at 1600 and $3400 \mathrm{~cm}^{-1}$ are associated to presence of water absorbed on the $\mathrm{ZnWO}_{4}$ 


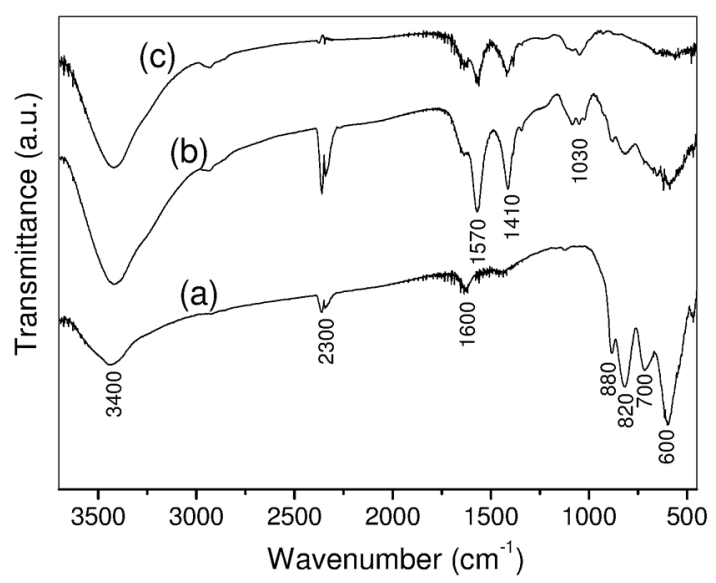

Figure 5: FTIR spectra of (a) $\mathrm{ZnWO}_{4}$ support, (b) immobilized enzyme on the $\mathrm{ZnWO}_{4}$ support and (c) free enzyme.

sample. These results indicate the formation of $\mathrm{ZnWO}_{4}$ single phase, corroborating to the results from XRD analysis. Bands around $2300 \mathrm{~cm}^{-1}$ are assigned to the adsorbed atmospheric $\mathrm{CO}_{2}$. Inulinase free (Figure 5c) shows bands associated with amino groups (CONH) at $1400-1600 \mathrm{~cm}^{-139,40}$. Bands around $1000 \mathrm{~cm}^{-1}$ correspond to $-\mathrm{C}=\mathrm{O}$ binding of enzyme on the support. These bands are also displayed in the spectrum of the immobilized enzyme on the support (Figure 5b), confirming the immobilization of inulinase on the $\mathrm{ZnWO}_{4}$ support.

According to the results of inulinase immobilization shown in Figure 6, it is possible to observe that the adsorption equilibrium was obtained in $120 \mathrm{~min}$ for both temperatures $\left(30\right.$ and $50^{\circ} \mathrm{C}$ ). Figure 6 also demonstrates that the increase of the temperature had a negative effect in the improvement of enzyme adsorption, with loading capacity of $605 \mathrm{U.g}^{-1}$

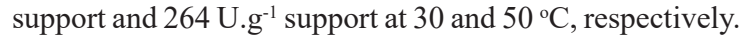
For comparison purposes, Missau et al. ${ }^{16}$ found similar results regarding the inulinase immobilization on alginate-chitosan

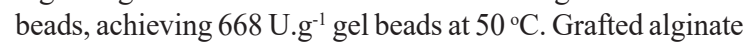
beads showed an inulinase loading capacity of $530{\mathrm{U} . \mathrm{g}^{-1} \mathrm{gel}}^{-1}$ beads ${ }^{19}$. Chitin ${ }^{21}$ and silica ${ }^{41}$ were used as inulinase supports,

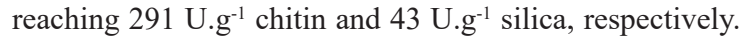
Therefore, these findings indicate that the $\mathrm{ZnWO}_{4}$ particles present satisfactory inulinase immobilization, which can be attributed to their porous structure.

\section{Conclusions}

$\mathrm{ZnWO}_{4}$ powders were successfully synthesized through one-step solvo-hydrothermal crystallization at a mild temperature, without using additives. $\mathrm{ZnWO}_{4}$ particles presented porous structure with surface area of $35.5 \mathrm{~m}^{2} \cdot \mathrm{g}^{-1}$. Inulinase could be successfully immobilized using $\mathrm{ZnWO}_{4}$ particles. Temperature had a significant effect on enzyme immobilization process. In the best condition, the enzyme

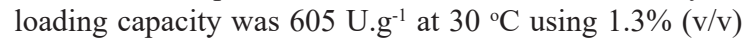
enzyme concentration and a 1:400 adsorbent:adsorbate ratio. Therefore, the $\mathrm{ZnWO}_{4}$ support prepared in this work shows attractive physical characteristics for the potential application on inulinase immobilization.

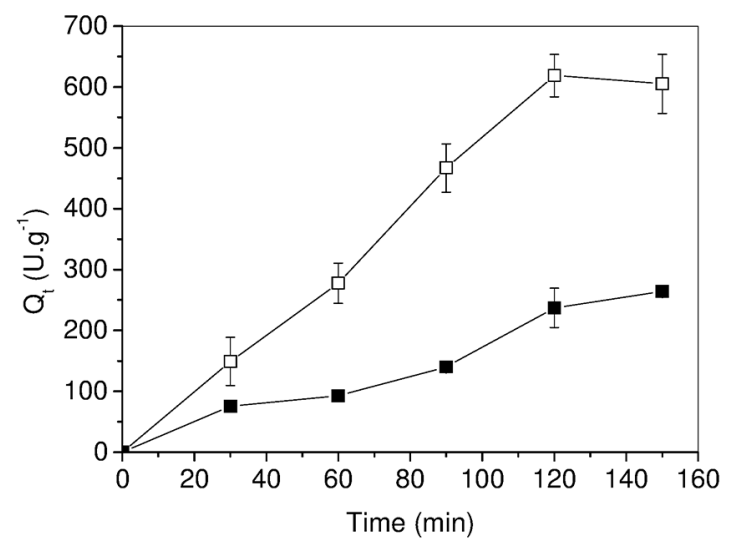

Figure 6: Inulinase adsorption capacity $\left(\mathrm{U}^{-\mathrm{g}^{-1}}\right)$ on $\mathrm{ZnWO}_{4}$ particles at $(\square) 30^{\circ} \mathrm{C}$ and (匹) $50{ }^{\circ} \mathrm{C}$.

\section{Acknowledgments}

The authors would like to thank CAPES and CNPq for their financial support and scholarships.

\section{References}

1. Zawawi SMM, Yahya R, Hassan A, Mahmud HNME, Daud $\mathrm{MN}$. Structural and optical characterization of metal tungstates $\left(\mathrm{MWO}_{4} ; \mathrm{M}=\mathrm{Ni}, \mathrm{Ba}, \mathrm{Bi}\right)$ synthesized by a sucrose-templated method. Chemistry Central Journal. 2013;7(1):80.

2. Kumar RD, Karuppuchamy S. Microwave-assisted synthesis of copper tungstate nanopowder for supercapacitor applications. Ceramics International. 2014;40(8):12397-12402.

3. Bavykina I, Angloher G, Hauff D, Kiefer M, Petricca F, Pröbst F. Development of cryogenic phonon detectors based on $\mathrm{CaMoO}_{4}$ and $\mathrm{ZnWO}_{4}$ scintillating crystals for direct dark matter search experiments. Optical Materials. 2009;31(10):1382-1387.

4. Kalinko A, Kuzmin A. Raman and photoluminescence spectroscopy of zinc tungstate powders. Journal of Luminescence. 2009;129(10):1144-1147.

5. Brik MG, Nagirnyi V, Kirm M. Ab-initio studies of the electronic and optical properties of $\mathrm{ZnWO}_{4}$ and $\mathrm{CdWO}_{4}$ single crystals. Materials Chemistry and Physics. 2012;134(2-3):1113-1120.

6. Kim DW, Cho IS, Shin SS, Lee S, Noh TH, Kim DH, et al. Electronic band structures and photovoltaic properties of $M \mathrm{WO}_{4}(M=$ $\mathrm{Zn}, \mathrm{Mg}, \mathrm{Ca}, \mathrm{Sr}$ ) compounds. Journal of Solid State Chemistry. 2011;184(8):2103-2107.

7. You L, Cao Y, Sun YF, Sun P, Zhang T, Du Y, et al. Humidity sensing properties of nanocrystalline $\mathrm{ZnWO}_{4}$ with porous structures. Sensors and Actuators B: Chemical. 2012;161(1):799-804.

8. Tang Z, Li X, Yang J, Yu J, Wang J, Tang Z. Mixed potential hydrogen sensor using $\mathrm{ZnWO}_{4}$ sensing electrode. Sensors and Actuators B: Chemical. 2014;195:520-525.

9. Cao X, Wu W, Chen N, Peng Y, Liu Y. An ether sensor utilizing cataluminescence on nanosized $\mathrm{ZnWO}_{4}$. Sensors and Actuators B: Chemical. 2009;137(1):83-87.

10. Fu H, Pan C, Zhang L, Zhu Y. Synthesis, characterization and photocatalytic properties of nanosized $\mathrm{Bi}_{2} \mathrm{WO}_{6}, \mathrm{PbWO}_{4}$ and $\mathrm{ZnWO}_{4}$ catalysts. Materials Research Bulletin. 2007;42(4):696-706. 
11. Zhang L, Wang Z, Wang L, Xing Y, Zhang Y. Preparation of $\mathrm{ZnWO}_{4}$ /graphene composites and its electrochemical properties for lithium-ion batteries. Materials Letters. 2013;108:9-12.

12. Daoud FBO, Kaddour S, Sadoun T. Adsorption of cellulase Aspergillus niger on a commercial activated carbon: Kinetics and equilibrium studies. Colloids and Surfaces B: Biointerfaces. 2010;75(1):93-99.

13. Fernandes P, Marques MPC, Carvalho F, Cabral JMS. A simple method for biocatalyst immobilization using PVA-based hydrogel particles. Journal of Chemical Technology and Biotechnology. 2009;84(4):561-564.

14. Garlet TB, Weber CT, Klaic R, Foletto EL, Jahn SL, Mazutti MA, et al. Carbon nanotubes as supports for inulinase immobilization. Molecules. 2014;19(9):14615-14624.

15. Elnashar MMM, Danial EN, Awad GEA. Novel carrier of grafted alginate for covalent immobilization of inulinase. Industrial \& Engineering Chemistry Research. 2009;48(22):9781-9785.

16. Missau J, Scheid AJ, Foletto EL, Jahn SL, Mazutti MA, Kuhn RC. Immobilization of commercial inulinase on alginate-chitosan beads. Sustainable Chemical Processes. 2014;2(1):13.

17. Brena B, González-Pombo P, Batista-Viera F. Immobilization of enzymes: A literature survey. Methods in Molecular Biology. 2013;1051:15-31.

18. Feng W, Ji P. Enzymes immobilized on carbon nanotubes. Biotechnology Advances. 2011;29(6):889-895.

19. Danial EN, Elnashar MMM, Awad GEA. Immobilized inulinase on grafted alginate beads prepared by the one-step and the twosteps methods. Industrial \& Engineering Chemistry Research. 2010;49(7):3120-3125.

20. Karimi M, Chaudhury I, Jianjun C, Safari M, Sadeghi R, Habibi-Rezaei $\mathrm{M}$, et al. Immobilization of endo-inulinase on non-porous amino functionalized silica nanoparticles. Journal of Molecular Catalysis B: Enzymatic. 2014;104:48-55.

21. Nguyen QD, Rezessy-Szabó JM, Czukor B, Hoschke Á. Continuous production of oligofructose syrup from Jerusalem artichoke juice by immobilized endo-inulinase. Process Biochemistry. 2011;46(1):298-303.

22. Ryu JH, Lim CS, Auh KH. Synthesis of $\mathrm{ZnWO}_{4}$ nanocrystalline powders, by the polymerized complex method. Materials Letters. 2003;57(9-10):1550-1554.

23. Kumar RD, Karuppuchamy S. Synthesis and characterization of nanostructured $\mathrm{Zn}-\mathrm{WO}_{3}$ and $\mathrm{ZnWO}_{4}$ by simple solution growth technique. Journal of Materials Science: Materials in Electronics. 2015;26(5):3256-3261.

24. Arin J, Dumrongrojthanath P, Yayapao O, Phuruangrat A, Thongtem S, Thongtem T. Synthesis, characterization and optical activity of La-doped $\mathrm{ZnWO}_{4}$ nanorods by hydrothermal method. Superlattices and Microstructures. 2014;67:197-206.

25. Kim MJ, Huh YD. Ligand-assisted hydrothermal synthesis of $\mathrm{ZnWO}_{4}$ rods and their photocatalytic activities. Materials Research Bulletin. 2010;45(12):1921-1924.
26. Hojamberdiev M, Zhu G, Xu Y. Template-free synthesis of $\mathrm{ZnWO}_{4}$ powders via hydrothermal process in a wide $\mathrm{pH}$ range. Materials Research Bulletin. 2010;45(12):1934-1940.

27. Kumar GB, Sivaiah K, Buddhudu S. Synthesis and characterization of $\mathrm{ZnWO}_{4}$ ceramic powder. Ceramics International. 2010;36(1):199-202.

28. Ungelenk J, Speldrich M, Dronskowski R, Feldmann C. Polyolmediated low-temperature synthesis of crystalline tungstate nanoparticles $\mathrm{MWO}_{4}(\mathrm{M}=\mathrm{Mn}, \mathrm{Fe}, \mathrm{Co}, \mathrm{Ni}, \mathrm{Cu}, \mathrm{Zn})$. Solid State Sciences. 2014;31:62-69.

29. Parhi P, Karthik TN, Manivannan V. Synthesis and characterization of metal tungstates by novel solid-state metathetic approach. Journal of Alloys and Compounds. 2008;465(1-2):380-386.

30. Mancheva M, Iordanova R, Dimitriev Y. Mechanochemical synthesis of nanocrystalline $\mathrm{ZnWO}_{4}$ at room temperature. Journal of Alloys and Compounds. 2011;509(1):15-20.

31. Wu Y, Zhang SC, Zhang LW, Zhu YF. Photocatalytic Activity of Nanosized $\mathrm{ZnWO}_{4}$ Prepared by the Sol-gel Method. Chemical Research in Chinese Universities. 2007;23(4):465-468.

32. Huang G, Zhu Y. Synthesis and photocatalytic performance of $\mathrm{ZnWO}_{4}$ catalyst. Materials Science and Engineering: $B$. 2007;139(2-3):201-208.

33. Dong T, Li Z, Ding Z, Wu L, Wang X, Fu X. Characterizations and properties of $\mathrm{Eu}^{3+}$-doped $\mathrm{ZnWO}_{4}$ prepared via a facile selfpropagating combustion method. Materials Research Bulletin. 2008;43(1):1694-1701.

34. Rahimi-Nasrabadi M, Pourmortazavi SM, Ganjali MR, Hajimirsadeghi SS, Zahedi MM. Electrosynthesis and characterization of zinc tungstate nanoparticles. Journal of Molecular Structure. 2013;1047:31-36.

35. Keereeta Y, Thongtem T, Thongtem S. Fabrication of $\mathrm{ZnWO}_{4}$ nanofibers by a high direct voltage electrospinning process. Journal of Alloys and Compounds. 2011;509(23):6689-6695.

36. Miller GL. Use of dinitrosalicylic acid reagent for determination of reducing sugar. Analytical Chemistry. 1959;31(3):426-428.

37. Jenkins R, Snyder RL. Introduction to X-ray powder diffractometry. New Jersey: John Wiley \& Sons; 1996. 432p.

38. Yu C, Yu JC. Sonochemical fabrication, characterization and photocatalytic properties of $\mathrm{Ag} / \mathrm{ZnWO}_{4}$ nanorod catalyst. Materials Science and Engineering: B. 2009;164(1):16-22.

39. Cipolatti EP, Valério A, Nicoletti G, Theilacker E, Araújo PHH, Sayer C, et al. Immobilization of Candida antarctica lipase B on PEGylated poly(urea-urethane) nanoparticles by step miniemulsion polymerization. Journal of Molecular Catalysis B: Enzymatic. 2014;109:116-121.

40. Verma ML, Barrow CJ, Kennedy JF, Puri M. Immobilization of $\beta$-D-galactosidase from Kluyveromyces lactis on functionalized silicon dioxide nanoparticles: Characterization and lactose hydrolysis. International Journal of Biological Macromolecules. 2012;50(1):432-437.

41. Gaspari JW, Gomes LH, Tavares FCA. Imobilização da inulinase de Kluyveromyces marxianus para a hidrólise de extratos de Helianthus tuberosus L. Scientia Agricola. 1999;56(4):1135-1140. 